\title{
Plant Oil
}

National Cancer Institute

\section{Source}

National Cancer Institute. Plant Oil. NCI Thesaurus. Code C79688.

Any oil derived from a plant or from a specific part of a plant. 